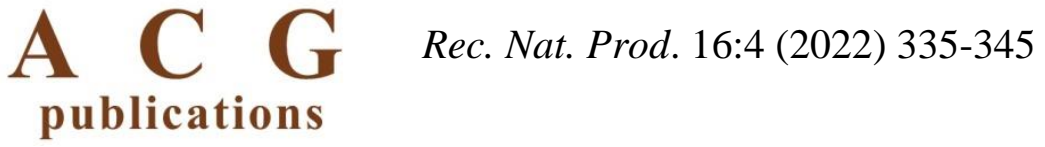

records of natural products

\title{
Essential Oil Composition and Antioxidant Activity of Endemic Achillea lingulata Waldst. \& Kit. Compared to Common A. millefolium $\mathrm{L}$.
}

\section{Dušan Čulum (1,2, Amira Čopra-Janićijević ${ }^{11,2}$, Edina Muratović ${ }^{2}$, Sonja Siljak-Yakovlev ${ }^{3,2}$, Milka Maksimović ${ }^{1,2}$ and Danijela Vidic ${ }^{1,2^{*}}$}

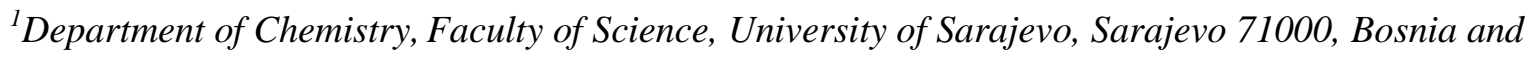 \\ Herzegovina \\ ${ }^{2}$ Laboratory for Research and Protection of Endemic Resources, Department of Biology, Faculty of \\ Science, University of Sarajevo, Sarajevo 71000, Bosnia and Herzegovina \\ ${ }^{3}$ Ecologie, Systématique, Evolution, Univ. Paris-Sud, UMR CNRS 8079, AgroParisTech, Université \\ Paris-Saclay, Orsay Cedex, France
}

(Received July 22, 2021; Revised September 20, 2021; Accepted September 21, 2021)

\begin{abstract}
In this study, the chemical composition and antioxidant activity of the hydrodistilled essential oil of Achillea lingulata, an endemic species of the Euro-Mediterranean region, originating from Bosnia and Herzegovina, was investigated for the first time. For comparison, an analysis of the essential oil of the widely distributed Achillea millefolium, which grows together in the same habitat, was made. Ninety-six components were identified in A. lingulata and A. millefolium oils comprising $97.8 \%$ and $85.8 \%$, of the total oil, respectively. The oil of $A$. lingulata was characterized by a high content of oxygenated monoterpenes $(76.8 \%)$. The main compounds were borneol (30.1\%), trans-verbenol (15.5\%), 2-tridecanone (12.2\%), fragranol (8.3\%), and myrtenol (7.9\%). In contrast, essential oil of $A$. millefolium had oxygenated sesquiterpenes $(60.8 \%)$ as the most abundant compounds, with elemol (32.9\%) as the main constituent. In addition, $\gamma$-eudesmol (12.9\%), caryophyllene oxide (7.7\%), transcaryophyllene $(5.7 \%)$ and $\gamma$-muurolene $(4.7 \%)$ were present in a significant percentage in A. millefolium oil. Antioxidant activity was tested by three methods, ABTS, DPPH and FRAP, and the obtained results showed low activity of both investigated oils.
\end{abstract}

Keywords: Achillea lingulata; Achillea millefolium; GC-MS; essential oil; terpenes; antioxidant activity. (C) 2021 ACG Publications. All rights reserved.

\section{Introduction}

Plant chemistry represents the basis for the use of herbs for various therapeutic purposes. A good knowledge of the chemical composition of plants enables a better understanding of their possible medicinal effects. The pharmacological effects of plants depend on their phytochemical constituents. Secondary plant metabolites have played an important role in traditional medicine and folk use. Today,

* Corresponding author: E-Mail: danijela.vidic@gmail.com; Phone:+387-33-279-899 Fax:+387 33649359 
they represent the main compounds for the development of new drugs for the treatment of various diseases [1].

Family Asteraceae (Compositae) contains about $10 \%$ of all flowering plants with over 1700 genera and 25000 species [2]. The genus Achillea L. (tribe Anthemideae) includes 110-140 species, suffruticose to herbaceous perennials, mainly native to SW Asia and SE Europe, and widespread in Euroasia and North America. Its representatives display significant ecological amplitude from the coastal to the alpine (nival) region and from arid to waterlogged habitats [3, 4].

Achillea species have a long history of use in traditional medicine due to their many health benefits. The main therapeutic applications are anti-inflammatory, wound healing, spasmolytic, choleretic abdominal pain, stomachache, symptomatic relief of colds, ulcer, and diarrhea [5, 6].

Phytochemical studies of the genus Achillea have shown that many chemical constituents of this genus are bioactive. Literature data indicate the presence of flavonoids, terpenoids, lignans, amino acid derivates, fatty acids and alkamides [7, 8].

Essential oils, as a part of the plant immune system, have numbers of important impacts in plant metabolism, their protection from predators and pests, in attracting pollinators and supporting seed dispersal by animals, the interactions of the plants with their environment etc. In addition, these oils are a powerful tool for a better understanding of plants phylogeny $[9,10]$.

Achillea lingulata Waldst. \& Kit. (Achillea sect. Anthemoideae s.1.) [4] an endemic species of the Euro-Mediterranean region is distributed throughout the SE parts of Europe, mainly the Balkan Peninsula, Carpathians and Belarus [11]. Populations of A. lingulata inhabit high mountain regions: pastures, grassy places and rarely rocky ground [12].

Achillea millefolium L. (Achillea sect. A. millefolium agg.) [4] is a common widespread plant native to North and Central America, Asia and Europe [11].

There are numerous scientific studies on the biological activity of essential oils and extracts of Achillea species such as antioxidant, anti-inflammatory, antibacterial, antifungal and herbicidal activity [5-7, 13-16]. Antioxidants play an important role in protecting against free radicals that cause oxidative stress in the body. Some natural plant products have the ability to neutralize free radicals and because of that more and more research is being conducted today leading to the discovery of new bioactive compounds. Methods for determining antioxidant activity are based on different mechanisms that determine the ability of individual compounds to act in different ways.

There is no data on the determination of the volatile constituents of the A. lingulata of Bosnian origin. According to literature data, the chemical composition of essential oil of A. lingulata was investigated by several authors for samples from Serbia [17-22], showing that these samples belong to the borneol chemotype. Some other authors have reported the presence of lignans [23, 24], fatty acids [25] and phenolic compounds [26, 27].

The composition of the essential oil of the commercially available sample A. millefolium from Bosnia and Herzegovina was determined by Vidic [15]. Also, this and closely related species growing in other regions of the world, has been the subject of numerous studies for years, mainly due to their medicinal properties. According to different authors, camphor, borneol, 1,8-cineole, $\alpha$ - and $\beta$-pinene, caryophyllene oxide, $\alpha$-bisabolol, nerolidol $\alpha$ - and $\beta$-thujone, ascaridole, chamazulene, piperitone, and artemisia ketone have been found as the main components in the essential oil of A. millefolium [15, 2835].

Volatile compounds can be a useful tool for chemotaxonomic classification that allows Achillea species to be divided into several groups. For species from the Balkan Peninsula, the most common group is with "1,8-cineole-camphor-borneol" chemotype [33]. Achillea lingulata can be observed separately because compounds in its essential oil are not significantly shared with other species. Research on the essential oil from A. millefolium has shown that ten different compounds can define the chemotype of this species [32].

The aim of this study was to investigate the volatile constituents of essential oils and antioxidant activity of A. lingulata, an endemic species of the Euro-Mediterranean region, and to compare its data, using the same analysis, with the well-known medicinal plant $A$. millefolium growing wild together in the same habitat and under the same environmental conditions.

These are the first data on the chemical composition of essential oil of Achillea lingulata from Bosnia and Herzegovina and its antioxidant activity. 


\section{Materials and Methods}

\subsection{Plant Material}

Plant material of Achillea lingulata and Achillea millefolium were collected in full blooming stage, on mountain Jahorina (Rajska vrata, cca $1600 \mathrm{~m}$ of altitude), Bosnia and Herzegovina, in July 2020. The vouchers are stored in the Herbarium of National Museum of Bosnia and Herzegovina, Herbarium code SARA (A. lingulata SARA - 52474, A. millefolium SARA - 52475). The samples were air-dried in room with ventilation at ambient temperature and stored in paper bags in a dry place, until use.

\subsection{Essential Oil Isolation}

The essential oils were isolated by hydrodistillation from aerial parts of the plant for $3 \mathrm{~h}$. The oil was extracted with dichloromethane and dried over anhydrous sodium sulfate. Dichloromethane was completely removed and extracted essential oil was stored at $4^{\circ} \mathrm{C}$ in the dark, until analysis. All of the applied chemicals were of pro analysis purity and were purchased from Sigma Aldrich.

\subsection{GC-MS Analysis}

Determination of volatile compounds from the aerial parts of the plants was analyzed by GC-MS Agilent Technologies Inc. GC7890A; MS 5975C with autosampler 7983. The GC conditions were: fused silica $\mathrm{HP}-5$ column, carrier gas $\mathrm{He}(1.0 \mathrm{~mL} / \mathrm{min})$, temperature was programmed from $60^{\circ} \mathrm{C}$ to $240^{\circ} \mathrm{C}$ with a temperature increase of $3^{\circ} \mathrm{C} / \mathrm{min}$; the injection port temperature was $250^{\circ} \mathrm{C}$; detector temperature was $280^{\circ} \mathrm{C}$. Ionization of the sample components was performed in the EI mode $(70 \mathrm{eV})$.

A mixture of $n$-alkanes (C8-C40) was injected under the above conditions to calculate the retention indices using the generalized equation [36] Retention indices of $n$-alkanes were used for recalculating retention indices of volatile constituents.

The identification of volatile constituents was performed by comparing their retention indices and MS spectra with those presented in the databases available in the licensed MassFinder 4 software (EssentialOil 4a and Adams2205 [37] databases). Oil samples were dissolved in $n$-hexane prior to GCMS analysis.

\subsection{Antioxidant Capacity Assays}

\subsubsection{ABTS Capacity}

The antioxidant activity of analyzed essential oils was determined by ABTS radical cation decolorization assay [38]. For this assay ABTS radical cation was prepared by mixing equal volumes of $7 \mathrm{mM}$ ABTS solution and $2.45 \mathrm{mM}$ solution of potassium persulfate, allowing the mixture to stand in the dark at temperature of $4^{\circ} \mathrm{C}$ for $12-16 \mathrm{~h}$ before use. To determine the antioxidant activity of the oils, $\mathrm{ABTS}^{+}$solution was diluted with ethanol to achieve an absorbance of $0.70-0.90$ at $734 \mathrm{~nm}$.

After adding $100 \mu \mathrm{L}$ of the sample solution in dimethyl sulfoxide to $1 \mathrm{~mL}$ of $\mathrm{ABTS}^{++}$solution, mixture was left in the dark for 10 minutes and absorbance was measured spectrophotometrically at 743 $\mathrm{nm}$. All measurements were performed in triplicate. The percentage inhibition of the $\mathrm{ABTS}^{++}$radical by the oils was calculated according to the formula:

$$
\% A A=\left(A_{0}-A_{t}\right) / A_{0} \times 100
$$

$\mathrm{A}_{0}-$ absorbance of ABTS $t=0$ min, $A_{t}-$ absorbance of ABTS with antioxidant $t=10$ min

The calibration curve was performed using Trolox as a standard, and the results were expressed as Trolox equivalent per gram of oil $(\mu \mathrm{M}(\mathrm{TE}) / \mathrm{g})$.

\subsubsection{DPPH Capacity}

The antioxidant activity of the oils was measured in terms of hydrogen donating radical scavenging ability, using the stable radical (2,2-diphenyl-1-picrylhydrazyl), DPPH [39]. Solution of DPPH radical was prepared dissolving DPPH in ethanol, and diluting to achieve absorbance of 0.70 
0.90, at $517 \mathrm{~nm}$. After addition of an aliquot $(100 \mu \mathrm{L})$ of diluted essential oil to $1 \mathrm{~mL}$ of DPPH solution, decrease of absorbance was measured at $517 \mathrm{~nm}$ after 30 minutes. Ethanol was used as a blank. All measurements were performed in triplicate.

The percentage of antioxidant activity for scavenging DPPH radical by essential oils was calculated according to the formula:

$$
\% \mathrm{AA}=\left(\mathrm{A}_{0}-\mathrm{A}_{\mathrm{t}}\right) / \mathrm{A}_{0} \times 100
$$

(1) $A_{0}$-absorbance of DPPH $t=0$ min, $A_{t}$-absorbance of DPPH with antioxidant $t=30 \mathrm{~min}$

The calibration curve was performed using Trolox as a standard and the results were expressed as Trolox equivalent per gram of oil $(\mu \mathrm{M}(\mathrm{TE}) / \mathrm{g})$.

\subsubsection{Ferric-Reducing Antioxidant Power Assay (FRAP)}

The FRAP (Ferric-Reducing Antioxidant Power Assay) assay is carried out under acidic conditions ( $\mathrm{pH}$ 3.6) to maintain iron solubility and more importantly, to stimulate electron transfer. The FRAP assay was performed according to the method described by Benzie and Strain [40] with minor modifications. The FRAP reagent was prepared fresh just before use by mixing: $300 \mathrm{mmol} / \mathrm{L}$ acetate buffer, $10 \mathrm{mmol} / \mathrm{L} \mathrm{TPTZ/EtOH}$ solution, and $20 \mathrm{mmol} / \mathrm{L}$ ferric chloride in this order at a volume ratio of 10:1:1 and then heated to $37^{\circ} \mathrm{C}$ before use. An aliquot of $0.1 \mathrm{~mL}$ of sample was allowed to react with $3.0 \mathrm{~mL}$ of the FRAP working solution and $0.3 \mathrm{~mL}$ of water. All readings were then taken at $593 \mathrm{~nm}$ against a blank reagent sample at the end of $6 \mathrm{~min}$. The results are expressed as L(+)-ascorbic acid equivalent per gram of oil, (mg AAE)/g).

\section{Results and Discussion}

\subsection{Essential Oil Composition}

The hydrodistillated oils of A. lingulata and A. millefolium were analysed by GC-MS technique. Despite the fact that both species grow in the same habitat under the same environmental conditions, significant differences in the content and composition of essential oils were observed. Both oils were light yellow color with a pleasant smell. The yield of hydrodistilled essential oil from the aerial parts of A. lingulata was low $0.01 \%$, while for A. millefolium it was $0.1 \%$. In general, A. lingulata was not rich in essential oil content, and its content varied from 0.05-0.22\% [17-22], depending on the parts of the plant that were used to obtain the oil.

The chemical composition of the essential oils for both species is presented in Table 1. Forty-two constituents were identified in A. lingulata oil, of which twenty-nine comprise $97.8 \%$ of the total oil. In addition, 13 components were identified, but their content was lower than $0.1 \%$ and they were marked as trace $(\mathrm{t})$. The oxygenated monoterpenes were dominant compounds $(76.8 \%)$, with a very low content of monoterpene hydrocarbons $(1.2 \%)$.

The obtained data showed that the essential oil of A. lingulata belongs to the borneol chemotype, with a borneol content of $30.1 \%$. Most samples from Serbia also had borneol as the main compound, (20.3\%) [17], (29.9\%) [18], (23 - 40.7\%) [20], (30.7\%) [21], only Boskovic [19] reported $\tau$-cadinol $(22.48 \%)$ as the main compound. The essential oil from underground parts (root) had neryl tiglate (16.2\%), as the main component [22].

The second most abundant compound is trans-verbenol (15.5\%), also oxygenated monoterpene. To the best of our knowledge this is the first report on the trans-verbenol content in the oil of the $A$. lingulata. As the main compound, in others Achillea species, verbenol (27.98\%) was found in A. lycaonica, an endemic species from Turkey [16]. Also, fragranol was detected for the first time in a significant amount (8.3\%) in the analyzed essential oil.

Components that do not belong to terpenoids are marked as others (OT) comprising (14.1\%), including 2-tridecanone (12.2\%) and alkanes. The presence of a high content of verbenol, fragranol and 2-tridecanone makes the chemical profile of A. lingulata from Bosnia and Herzegovina specific. 
Table 1. Chemical composition of essential oil of A. lingulata and A. millefolium

\begin{tabular}{|c|c|c|c|c|c|}
\hline \multirow{2}{*}{ Compounds } & \multirow{2}{*}{$\mathbf{R} \mathbf{I}^{\mathbf{a}, \mathbf{b}}$} & \multirow{2}{*}{ RI } & \multicolumn{2}{|c|}{ Relative content (\%) } & \multirow{2}{*}{$\mathbf{I M}^{\mathbf{c}}$} \\
\hline & & & A. lingulata & A. millefolium & \\
\hline Thuja-2,4 (10)-diene & $953^{\mathrm{a}}$ & 946 & 0.8 & - & $\mathrm{RI}^{\mathrm{a}}$, MS \\
\hline$m$-Cymene & $1013^{b}$ & 1002 & 0.2 & - & $\mathrm{RI}^{\mathrm{b}}, \mathrm{MS}$ \\
\hline$p$-Cymene & $1020^{\mathrm{a}}$ & 1020 & 0.2 & - & $\mathrm{RI}^{\mathrm{a}}$, MS \\
\hline 1,8-Cineol & $1026^{\mathrm{a}}$ & 1026 & 0.6 & 0.4 & $\mathrm{RI}^{\mathrm{a}}$, MS \\
\hline cis-Sabinene hydrate & $1065^{\mathrm{a}}$ & 1062 & 0.3 & $\mathrm{t}$ & $\mathrm{RI}^{\mathrm{a}}$, MS \\
\hline trans-Sabinene hydrate & $1098^{a}$ & 1095 & 0.4 & $\mathrm{t}$ & $\mathrm{RI}^{\mathrm{a}}$, MS \\
\hline dehydro Sabina ketone & $1117^{\mathrm{a}}$ & 1117 & 0.4 & - & $\mathrm{RI}^{\mathrm{a}}$, MS \\
\hline trans-Pinocarveol & $1135^{\mathrm{a}}$ & 1135 & 3.3 & 0.1 & $\mathrm{RI}^{\mathrm{a}}$, MS \\
\hline trans-Sabinol & $1137^{\mathrm{a}}$ & 1137 & $\mathrm{t}$ & - & $\mathrm{RI}^{\mathrm{a}}$, MS \\
\hline Camphor & $1141^{\mathrm{a}}$ & 1140 & - & 0.5 & $\mathrm{RI}^{\mathrm{a}}$, MS \\
\hline trans-Verbenol & $1140^{\mathrm{b}}$ & 1141 & 15.5 & - & $\mathrm{RI}^{\mathrm{b}}$, MS \\
\hline Sabina ketone & $1154^{\mathrm{a}}$ & 1154 & 0.4 & - & $\mathrm{RI}^{\mathrm{a}}$, MS \\
\hline Pinocarvone & $1160^{\mathrm{a}}$ & 1159 & 1.6 & 0.1 & $\mathrm{RI}^{\mathrm{a}}$, MS \\
\hline Borneol & $1165^{\mathrm{a}}$ & 1162 & 30.1 & 2.0 & $\mathrm{RI}^{\mathrm{a}}$, MS \\
\hline Lavandulol & $1165^{\mathrm{a}}$ & 1164 & - & 1.0 & $\mathrm{RI}^{\mathrm{a}}$, MS \\
\hline Terpinen-4-ol & $1174^{\mathrm{a}}$ & 1174 & 2.6 & 0.2 & $\mathrm{RI}^{\mathrm{a}}$, MS \\
\hline p-Cymene-8-ol & $1179^{\mathrm{a}}$ & 1182 & 0.3 & - & $\mathrm{RI}^{\mathrm{a}}$, MS \\
\hline$\alpha$-Terpineol & $1186^{\mathrm{a}}$ & 1188 & 0.1 & 1.0 & $\mathrm{RI}^{\mathrm{a}}$, MS \\
\hline Myrtenol & $1194^{\mathrm{a}}$ & 1193 & 7.9 & 0.2 & $\mathrm{RI}^{\mathrm{a}}$, MS \\
\hline$\alpha$-Camphonelol & $1190^{\mathrm{b}}$ & 1200 & - & $\mathrm{t}$ & $\mathrm{RI}^{\mathrm{b}}$, MS \\
\hline Verbenone & $1204^{\mathrm{a}}$ & 1206 & 1.3 & - & $\mathrm{RI}^{\mathrm{a}}$, MS \\
\hline Fragranol & $1214^{\mathrm{a}}$ & 1212 & 8.3 & - & $\mathrm{RI}^{\mathrm{a}}$, MS \\
\hline trans-Carveol & $1215^{\mathrm{a}}$ & 1216 & $\mathrm{t}$ & 0.1 & $\mathrm{RI}^{\mathrm{a}}$, MS \\
\hline$m$-Cumenol & $1224^{\mathrm{a}}$ & 1226 & $\mathrm{t}$ & - & $\mathrm{RI}^{\mathrm{a}}$, MS \\
\hline Cumin aldehyde & $1238^{a}$ & 1237 & 0.2 & - & $\mathrm{RI}^{\mathrm{a}}$, MS \\
\hline Bornyl acetate & $1284^{\mathrm{a}}$ & 1284 & 2.2 & 0.2 & $\mathrm{RI}^{\mathrm{a}}$, MS \\
\hline$p$-Cymen-7-ol & $1289^{\mathrm{a}}$ & 1288 & $\mathrm{t}$ & - & $\mathrm{RI}^{\mathrm{a}}$, MS \\
\hline Chrysanthenone epoxide & $1290^{\mathrm{b}}$ & 1316 & $\mathrm{t}$ & - & $\mathrm{RI}^{\mathrm{b}}$, MS \\
\hline$p$-vinyl-Guaiacol & $1309^{a}$ & 1327 & - & 0.2 & $\mathrm{RI}^{\mathrm{a}}$, MS \\
\hline trans-Carvyl acetate & $1339^{\mathrm{a}}$ & 1337 & - & $\mathrm{t}$ & $\mathrm{RI}^{\mathrm{a}}$, MS \\
\hline Fragranyl acetate & $1331^{\mathrm{b}}$ & 1343 & 1.3 & - & $\mathrm{RI}^{\mathrm{b}}, \mathrm{MS}$ \\
\hline Eugenol & $1356^{\mathrm{a}}$ & 1356 & $\mathrm{t}$ & 0.2 & $\mathrm{RI}^{\mathrm{a}}$, MS \\
\hline Anethol epoxide & $1347^{\mathrm{b}}$ & 1363 & - & 0.2 & $\mathrm{RI}^{\mathrm{b}}$, MS \\
\hline$\alpha$-Copaene & $1374^{\mathrm{a}}$ & 1373 & - & $\mathrm{t}$ & $\mathrm{RI}^{\mathrm{a}}$, MS \\
\hline$\beta$-Bourbonene & $1387^{\mathrm{a}}$ & 1382 & - & 0.2 & $\mathrm{RI}^{\mathrm{a}}$, MS \\
\hline$\beta$-Cubebene & $1387^{\mathrm{a}}$ & 1388 & - & $\mathrm{t}$ & $\mathrm{RI}^{\mathrm{a}}$, MS \\
\hline$\beta$-Elemene & $1389^{a}$ & 1390 & - & 0.1 & $\mathrm{RI}^{\mathrm{a}}$, MS \\
\hline (Z)-Jasmone & $1392^{\mathrm{a}}$ & 1397 & $\mathrm{t}$ & $\mathrm{t}$ & $\mathrm{RI}^{\mathrm{a}}$, MS \\
\hline$a$-Chamipinene & $1396^{\mathrm{a}}$ & 1400 & - & $\mathrm{t}$ & $\mathrm{RI}^{\mathrm{a}}$, MS \\
\hline trans-Caryophyllene & $1417^{\mathrm{a}}$ & 1417 & - & 5.7 & $\mathrm{RI}^{\mathrm{a}}$, MS \\
\hline$\beta$-Copaene & $1430^{\mathrm{a}}$ & 1426 & - & 0.1 & $\mathrm{RI}^{\mathrm{a}}$, MS \\
\hline$\beta$-Gurjunene & $1431^{\mathrm{a}}$ & 1433 & - & $\mathrm{t}$ & $\mathrm{RI}^{\mathrm{a}}$, MS \\
\hline Aromadendrene & $1439^{a}$ & 1441 & - & $\mathrm{t}$ & $\mathrm{RI}^{\mathrm{a}}$, MS \\
\hline$\alpha$-Humulene & $1452^{\mathrm{a}}$ & 1450 & - & 1.0 & $\mathrm{RI}^{\mathrm{a}}$, MS \\
\hline allo-Aromadendrene & $1458^{\mathrm{a}}$ & 1457 & - & 0.1 & $\mathrm{RI}^{\mathrm{a}}$, MS \\
\hline cis-Cadina-1(6)-4-diene & $1461^{\mathrm{a}}$ & 1460 & - & $\mathrm{t}$ & $\mathrm{RI}^{\mathrm{a}}$, MS \\
\hline Dauca-5,8-diene & $1471^{\mathrm{a}}$ & 1474 & - & 0.3 & $\mathrm{RI}^{\mathrm{a}}$, MS \\
\hline Dodecanol & $1469^{\mathrm{a}}$ & 1475 & 0.5 & - & $\mathrm{RI}^{\mathrm{a}}, \mathrm{MS}$ \\
\hline
\end{tabular}


Essential oil of A. lingulata and A. millefolium

Table 1 continued..

\begin{tabular}{|c|c|c|c|c|c|}
\hline$\gamma$-Muurolene & $1478^{\mathrm{a}}$ & 1478 & - & 4.7 & $\mathrm{RI}^{\mathrm{a}}, \mathrm{MS}$ \\
\hline ar-Curcumene & $1479^{\mathrm{a}}$ & 1481 & - & 0.7 & $\mathrm{RI}^{\mathrm{a}}, \mathrm{MS}$ \\
\hline Germacrene D & $1484^{\mathrm{a}}$ & 1489 & - & $\mathrm{t}$ & $\mathrm{RI}^{\mathrm{a}}, \mathrm{MS}$ \\
\hline$\alpha$-Zingiberene & $1493^{\mathrm{a}}$ & 1494 & - & 0.9 & $\mathrm{RI}^{\mathrm{a}}, \mathrm{MS}$ \\
\hline Viridiflorene & $1496^{\mathrm{a}}$ & 1501 & - & $\mathrm{t}$ & $\mathrm{RI}^{\mathrm{a}}, \mathrm{MS}$ \\
\hline 2-Tridecanone & $1495^{\mathrm{a}}$ & 1504 & 12.2 & - & $\mathrm{RI}^{\mathrm{a}}, \mathrm{MS}$ \\
\hline trans- $\beta$-Guaiane & $1502^{\mathrm{a}}$ & 1505 & - & $\mathrm{t}$ & $\mathrm{RI}^{\mathrm{a}}, \mathrm{MS}$ \\
\hline$\beta$-Bisabolene & $1505^{\mathrm{a}}$ & 1507 & - & $\mathrm{t}$ & $\mathrm{RI}^{\mathrm{a}}, \mathrm{MS}$ \\
\hline$\gamma$-Cadinene & $1513^{\mathrm{a}}$ & 1511 & - & 0.4 & $\mathrm{RI}^{\mathrm{a}}, \mathrm{MS}$ \\
\hline$(E)-\gamma$-Bisabolene & $1521^{\mathrm{b}}$ & 1519 & - & 0.6 & $\mathrm{RI}^{\mathrm{b}}, \mathrm{MS}$ \\
\hline$\delta$-Cadinene & $1522^{\mathrm{a}}$ & 1522 & - & 1.1 & $\mathrm{RI}^{\mathrm{a}}, \mathrm{MS}$ \\
\hline$(E)$-iso- $\gamma$-Bisabolene & $1528^{\mathrm{a}}$ & 1529 & - & $\mathrm{t}$ & $\mathrm{RI}^{\mathrm{a}}, \mathrm{MS}$ \\
\hline$\alpha$-Cadinene & $1537^{\mathrm{a}}$ & 1535 & - & 0.2 & $\mathrm{RI}^{\mathrm{a}}, \mathrm{MS}$ \\
\hline Elemol & $1548^{a}$ & 1551 & - & 32.9 & $\mathrm{RI}^{\mathrm{a}}, \mathrm{MS}$ \\
\hline Salviadienol & $1545^{\mathrm{b}}$ & 1554 & - & $\mathrm{t}$ & $\mathrm{RI}^{\mathrm{b}}, \mathrm{MS}$ \\
\hline$(E)$-Nerolidol & $1561^{\mathrm{a}}$ & 1564 & - & 0.6 & $\mathrm{RI}^{\mathrm{a}}, \mathrm{MS}$ \\
\hline Spathulenol & $1577^{\mathrm{a}}$ & 1576 & 3.3 & $\mathrm{t}$ & $\mathrm{RI}^{\mathrm{a}}, \mathrm{MS}$ \\
\hline Caryophyllene oxide & $1582^{\mathrm{a}}$ & 1579 & $\mathrm{t}$ & 7.7 & $\mathrm{RI}^{\mathrm{a}}, \mathrm{MS}$ \\
\hline Lemnalol & $1579^{b}$ & 1583 & $\mathrm{t}$ & - & $\mathrm{RI}^{\mathrm{b}}, \mathrm{MS}$ \\
\hline Ledol & $1602^{\mathrm{a}}$ & 1600 & $\mathrm{t}$ & - & $\mathrm{RI}^{\mathrm{a}}, \mathrm{MS}$ \\
\hline Eremoligenol & $1629^{\mathrm{a}}$ & 1616 & - & $\mathrm{t}$ & $\mathrm{RI}^{\mathrm{a}}, \mathrm{MS}$ \\
\hline$\gamma$-Eudesmol & $1630^{\mathrm{a}}$ & 1631 & - & 12.9 & $\mathrm{RI}^{\mathrm{a}}, \mathrm{MS}$ \\
\hline Caryophylla-3(15),7(14)-dien-6-ol & $1635^{\mathrm{b}}$ & 1635 & - & 1.1 & $\mathrm{RI}^{\mathrm{b}}, \mathrm{MS}$ \\
\hline Hinesol & $1640^{\mathrm{a}}$ & 1637 & - & $\mathrm{t}$ & $\mathrm{RI}^{\mathrm{a}}, \mathrm{MS}$ \\
\hline$\beta$-Eudesmol & $1649^{\mathrm{a}}$ & 1646 & 1.5 & - & $\mathrm{RI}^{\mathrm{a}}, \mathrm{MS}$ \\
\hline$\alpha$-Cadinol & $1652^{\mathrm{a}}$ & 1650 & $\mathrm{t}$ & - & $\mathrm{RI}^{\mathrm{a}}, \mathrm{MS}$ \\
\hline$\alpha$-Eudesmol & $1652^{\mathrm{a}}$ & 1652 & - & $\mathrm{t}$ & $\mathrm{RI}^{\mathrm{a}}, \mathrm{MS}$ \\
\hline Germacra-4 (15),5,10(14)-trien-1- $\alpha$-ol & $1685^{\mathrm{a}}$ & 1684 & 0.9 & 1.8 & $\mathrm{RI}^{\mathrm{a}}, \mathrm{MS}$ \\
\hline Shyobunol & $1688^{\mathrm{a}}$ & 1688 & - & 1.1 & $\mathrm{RI}^{\mathrm{a}}, \mathrm{MS}$ \\
\hline Eudesm-7(11)-en-4-ol & $1700^{\mathrm{a}}$ & 1702 & - & 0.2 & $\mathrm{RI}^{\mathrm{a}}, \mathrm{MS}$ \\
\hline Chamazulene & $1730^{\mathrm{a}}$ & 1725 & - & 0.8 & $\mathrm{RI}^{\mathrm{a}}, \mathrm{MS}$ \\
\hline 6S,7R-Bisabolone & $1748^{\mathrm{a}}$ & 1744 & - & 0.6 & $\mathrm{RI}^{\mathrm{a}}, \mathrm{MS}$ \\
\hline$\beta$-Costol & $1766^{\mathrm{a}}$ & 1762 & - & 0.6 & $\mathrm{RI}^{\mathrm{a}}, \mathrm{MS}$ \\
\hline$\alpha$-Costol & $1773^{\mathrm{a}}$ & 1768 & - & 0.6 & $\mathrm{RI}^{\mathrm{a}}, \mathrm{MS}$ \\
\hline Cryptomeridiol & $1813^{\mathrm{a}}$ & 1807 & - & 0.5 & $\mathrm{RI}^{\mathrm{a}}, \mathrm{MS}$ \\
\hline Hexahydrofarnesyl acetone & $1817^{\mathrm{b}}$ & 1845 & - & 0.2 & $\mathrm{RI}^{\mathrm{b}}, \mathrm{MS}$ \\
\hline Cembrene & $1937^{\mathrm{a}}$ & 1937 & - & $\mathrm{t}$ & $\mathrm{RI}^{\mathrm{a}}, \mathrm{MS}$ \\
\hline $\begin{array}{l}\text { trans-2,6-Dimethyl-10(p-tolyl)-undeca-2,6- } \\
\text { diene }\end{array}$ & $1945^{b}$ & 1951 & - & 0.7 & $\mathrm{RI}^{\mathrm{b}}, \mathrm{MS}$ \\
\hline cis- $\gamma$-Curcumyl-2-methylbutyrate & $2011^{\mathrm{b}}$ & 2008 & - & 0.2 & $\mathrm{RI}^{\mathrm{b}}, \mathrm{MS}$ \\
\hline Octadecanol & $2077^{\mathrm{a}}$ & 2085 & $\mathrm{t}$ & - & $\mathrm{RI}^{\mathrm{a}}, \mathrm{MS}$ \\
\hline Docosane & $2200^{\mathrm{a}}$ & 2200 & $\mathrm{t}$ & - & $\mathrm{RI}^{\mathrm{a}}, \mathrm{MS}$ \\
\hline Tricosane & $2300^{\mathrm{a}}$ & 2300 & 0.5 & 0.4 & $\mathrm{RI}^{\mathrm{a}}, \mathrm{MS}$ \\
\hline Tetracosane & $2400^{\mathrm{a}}$ & 2400 & 0.1 & $\mathrm{t}$ & $\mathrm{RI}^{\mathrm{a}}, \mathrm{MS}$ \\
\hline Pentacosane & $2500^{\mathrm{a}}$ & 2499 & 0.8 & 0.3 & $\mathrm{RI}^{\mathrm{a}}, \mathrm{MS}$ \\
\hline Heptacosane & $2700^{\mathrm{a}}$ & 2700 & - & 0.1 & $\mathrm{RI}^{\mathrm{a}}, \mathrm{MS}$ \\
\hline Nonacosane & $2900^{\mathrm{a}}$ & 2900 & - & 0.1 & $\mathrm{RI}^{\mathrm{a}}, \mathrm{MS}$ \\
\hline
\end{tabular}


Table 1 continued.

\begin{tabular}{|c|c|c|}
\hline Monoterpene hydrocarbons & 1.2 & - \\
\hline Oxygenated monoterpenes & 76.8 & 6.4 \\
\hline Sesquiterpenes & - & 16.0 \\
\hline Oxygenated sesquiterpenes & 5.7 & 60.6 \\
\hline Diterpenes & - & 0.7 \\
\hline Oxygenated diterpenes & - & 0.2 \\
\hline Other & 14.1 & 1.9 \\
\hline TOTAL & 97.8 & 85.8 \\
\hline
\end{tabular}

Sesquiterpene hydrocarbons were not identified, while oxygenated sesquiterpenes accounted for $5.7 \%$, and spathulenol (3.3\%) were the most abundant representatives.

In general, A. millefolium oil was characterized by a high percentage of oxygenated sesquiterpenes. Besides elemol (32.9\%) as the main compound, other compounds with a high amount were $\gamma$-eudesmol (12.9\%) and carophyllene oxide $(7.7 \%)$. Monoterpene hydrocarbons were not detected, while oxygenated monoterpenes comprised $6.7 \%$ of the total oil. Two diterpenes and one oxygenated diterpene were also identified in A. millefolium oil.

The only data on the chemical composition of essential oil of A. millefolium from Bosnia and Herzegovina [15] are those for a commercially available sample from an herbal store. This sample was characterized by a high content of oxygenated monoterpenes (80.4\%), with camphor $(19.2 \%)$ and borneol (15.1\%) as the main constituents. Oil of A. millefolium shows differences in chemical composition depending on origin, phenologic phase, and the part of the plant [28-30, 41, 42].

According to Nemeth [32], more than 10 components were found to be the main constituents of A. millefolium essential oils, which making it difficult to define a characteristic chemotype. Our results confirmed the complexity of the chemical composition of essential oil of A. millefolium which is evidenced by the new chemotype for A. millefolium from Bosnia and Herzegovina.

It is known that the content of some components in essential oils is highly dependent on environmental factors, such as altitude. The content of $\alpha$ - and $\beta$-thujone, which occurs in A. millefolium, decreases and eventually disappears with increasing elevation, [41], while the content of some other components e.g., trans-caryophyllene and $\gamma$-muurolene remains unchanged. The results of our analyzes for A. millefolium oil are in accordance with these statements, since for samples collected at about 1700 $\mathrm{m}$ above sea level, none of the thujones was detected in the oil, while the presence of transcaryophyllene $5.7 \%$ and $\gamma$-muurolene $4.7 \%$ was recorded. These data confirm that the composition of the essential oil, as part of the plant's immune system, depends on environmental conditions.

In conclusion, the essential oil composition of two Achillea species that grow in the same habitat and are collected at the same time differs significantly. Quantitative and qualitative differences in the profile of essential oils of the two Achillea species are notable.

The main component of A. millefolium was sesquiterpene elemol (32.9\%) which was not detected in essential oil of $A$. lingulata, while the main component of $A$. lingulata essential oil, borneol $(30.1 \%)$, was identified in a low amount of $2.0 \%$ in A. millefolium oil. Components, other than borneol, whose content in A. lingulata essential oil is greater than $1 \%$, in essential oil of A. millefolium oil occur in traces or in a percentage not exceeding $0.2 \%$ and vice versa.

Oxygenated terpenes are dominant in both oils, but oxygenated monoterpenes represent more than three quarters of the total oil (76.8\%) in A. lingulata, while oxygenated sesquiterpenes are the most abundant in essential oil of A. millefolium (60.6\%) (Figure 1). 


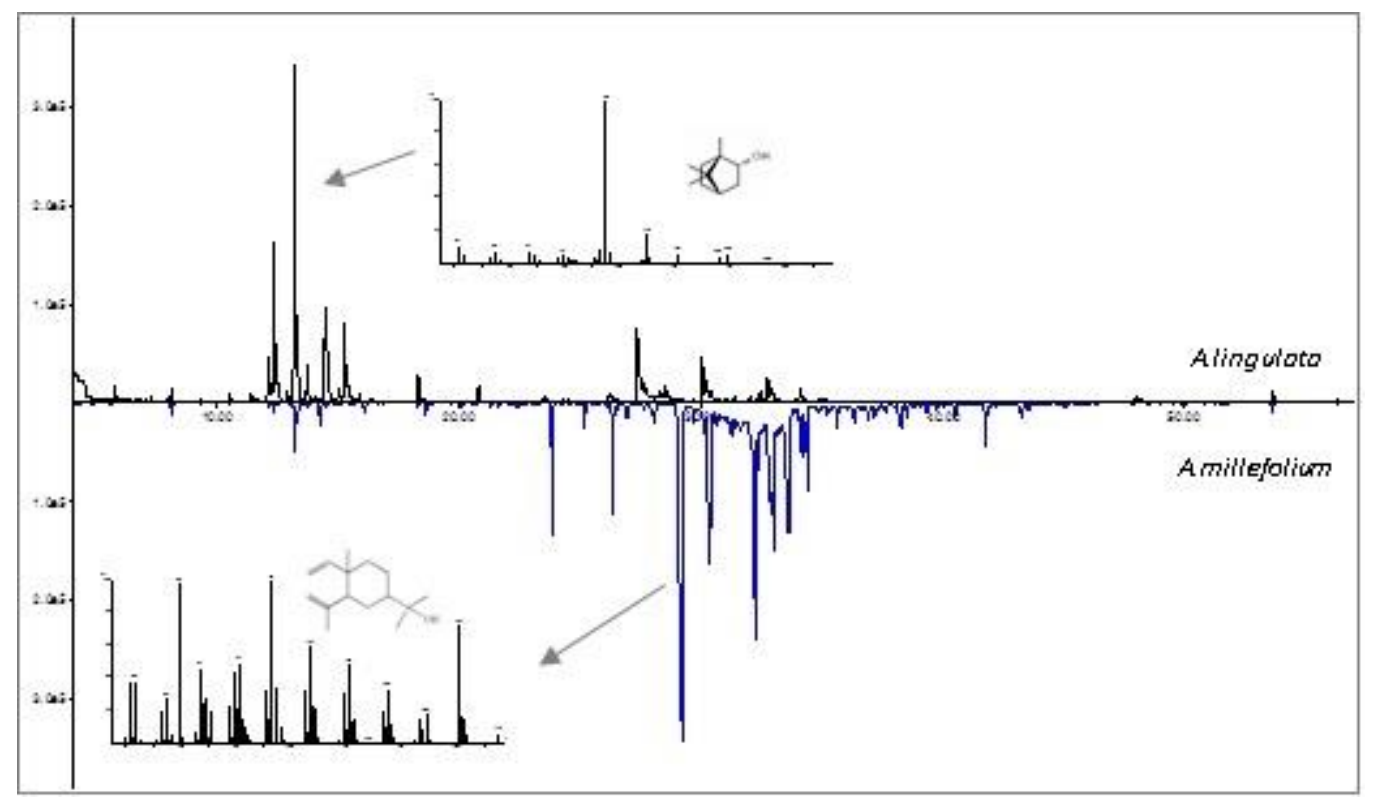

Figure 1. Gas chromatograms of A. lingulata and A. millefolium

\subsection{Antioxidant Activity}

The antioxidant activity of isolated essential oils was determined using three different antioxidant methods, ABTS, DPPH and FRAP. The chemical profile of the oils of two Achillea species showed significant differences, but although the oil composition was different, both oils showed low antioxidant activity. The results were expressed as Trolox equivalents (Table 2) for ABTS and DPPH method and as L(+)-ascorbic acid equivalent for FRAP method.

Table 2. Antioxidant activity of essential oil of A. lingulata and A. millefolium

\begin{tabular}{llll}
\hline \multirow{2}{*}{ Sample } & ABTS & DPPH & FRAP \\
\cline { 2 - 4 } & $\mu \mathrm{M}(\mathrm{TE}) / \mathrm{g}$ & $\mu \mathrm{M}(\mathrm{TE}) / \mathrm{g}$ & $\mathrm{mg}(\mathrm{AAE}) / \mathrm{g}$ \\
\hline A. lingulata & $17.86 \pm 0.76$ & $0.0158 \pm 0.0006$ & $12.88 \pm 0.24$ \\
A. millefolium & $71.21 \pm 0.33$ & $0.0099 \pm 0.0001$ & $32.03 \pm 0.91$ \\
\hline $\begin{array}{l}(\mu \mathrm{M}(\mathrm{TE}) / \mathrm{g}) \\
\text { of oil }\end{array}$ & &
\end{tabular}

These are the first results of the antioxidant activity of essential oil for A. lingulata. The only data on the antioxidant activity of $A$. lingulata are related to extracts obtained with different solvents and the results showed that extracts had a good antioxidant activity depending on the used solvent [27].

For ABTS method, A. lingulata oil had $17.86 \mu \mathrm{M}$ (TE)/g and the ability to reduce the stabile DPPH radical was $0.0158 \mu \mathrm{M}$ (TE)/g. The ability to reduce stabile DPPH radical was also weak for $A$. millefolium oil and was $0.0099 \mu \mathrm{M}(\mathrm{TE}) / \mathrm{g}$, but for the ABTS method this oil had almost four times higher activity than A. lingulata oil and amounted $71.21 \mu \mathrm{M}$ (TE)/g. The results obtained by the FRAP method also showed low antioxidant activity for both analyzed essential oils. Achillea millefolium oil had a better antioxidant activity $32.03 \mathrm{mg}$ (AAE)/g, than A. lingulata $12.88 \mathrm{mg}$ (AAE)/g.

According to literature data [15], the antioxidant activity of oil obtained from a commercial sample of A. millefolium from Bosnia and Herzegovina, was low for DPPH assay $\left(\mathrm{IC}_{50}=32.75 \mathrm{~g} / \mathrm{mL}\right)$ while the ability to reduce ABTS radical was higher $\left(\mathrm{IC}_{50}, 0.34 \mathrm{mg} / \mathrm{mL}\right)$. Low antioxidant activity for the DPPH method was also reported by Kazemi [43] $\left(\mathrm{IC}_{50}=22.11 \mathrm{mg} / \mathrm{mL}\right)$, although some samples of essential oil of $A$. millefolium showed high activity $\left(\mathrm{IC}_{50}=1.56 \mu \mathrm{g} / \mathrm{mL}\right)$ [44] $(15.12 \mu \mathrm{g} / \mathrm{mL})$ [45].

Our results showed significant differences in the chemical composition of the oils of two Achillea species growing wild together. In conclusion, the chemical composition of $A$. lingulata essential oil was different from other previous analyzes of this oil. To the best of our knowledge this is the first time that 
trans-verbenol, fragranol and 2-tridecanone have been detected in A. lingulata. The sample of $A$. millefolium differed from other published data, as elemol chemotype oil.

It is well known that antioxidant activity depends on the chemical composition where all constituents are in a synergistic or antagonistic relation. Good antioxidant activity of the essential oil is related to the content of the phenolic type terpenes such as thymol, carvacrol, carnosol, carnosolic acid, which are not found in the analyzed oils. Both oils showed low antioxidant activity by DPPH, ABTS and FRAP methods, so regardless of the differences in chemical composition, we can conclude that the components presented in the oil of the two investigated species are not good antioxidants and they have no synergistic effect.

The significance of this research is in the presentation of the content and composition of the essential oil of endemic Achillea lingulata from Bosnia and Herzegovina for the first time and its antioxidant activity, as well as the detection of a new chemotype of the well-known A. millefolium.

These results confirm again that the chemical profile of the essential oil is variable with respect to environmental factors. This variability forms the backbone of the problem in chemotaxonomic studies.

On the other hand, differences found in the composition of essential oils between two Achillea species growing in the same habitats indicate their genetic determinism.

\section{Acknowledgments}

This study was supported by the Ministry for Education, Science and Youth Grant No 11/05-1427626-1/19, Canton Sarajevo, Bosnia and Herzegovina.

\section{ORCID}

Dušan Čulum: 0000-0002-9044-4013

Amira Čopra-Janićijević: 0000-0003-1677-6850

Edina Muratović: 0000-0002-9828-3517

Sonja Siljak-Yakovlev: 0000-0002-6247-3351

Milka Maksimović: 0000-0001-7008-4500

Danijela Vidic: 0000-0003-2705-5936

\section{References}

[1] C. Venkataramaiah (2020). Phytoconstituents of the plants: The vital carters of the pharmacological deeds, In: Research Trends in Medicinal Plant Sciences, AkiNik Publications, New Delhi, pp. 1-24.

[2] J.R. Mandel, R.B. Dikow, C.M. Siniscalchi, R. Thapa, L.E. Watson and V.A. Funk (2019). A fully resolved backbone phylogeny reveals numerous dispersals and explosive diversifications throughout the history of Asteraceae, Proc. Natl. Acad. Sci. 116 (28), 14083-14088.

[3] Y.P. Guo, F. Ehrendorfer and R. Samuel (2004). Phylogeny and systematics of Achillea (Asteraceae Anthemideae) inferred from nrITS and plastid trnLF DNA sequences, Taxon 53 (3), 657-672A.

[4] F. Ehrendorfer and Y.P. Guo (2006) Multidisciplinary studies on Achillea sensu lato (CompositaeAnthemideae): new data on systematics and phylogeography, Willdenowia 36: 69-87.

[5] M. Mohammadhosseini, S.D. Sarker and A. Akbarzadeh (2017). Chemical composition of the essential oils and extracts of Achillea species and their biological activities: A review, J. Ethnopharmacol. 199, 257-315.

[6] F.P. Turkmenoglu, O.T. Agar, G. Akaydin, M. Hayran and B. Demirci (2015). Characterization of volatile compounds of eleven Achillea species from Turkey and biological activities of essential oil and methanol extract of A. hamzaoglui Arabac1 \& Budak, Molecules 20 (6), 11432-11458.

[7] X.T. Si, M.L. Zhang, Q.W. Shi, and H. Kiyota (2006). Chemical constituents of the plants in the genus Achillea. Chem. Biodiver. 3 (11), 1163-1180.

[8] S. Saeidnia, A.R. Gohari, N. Mokhber-Dezfuli and F. Kiuchi (2011). A review on phytochemistry and medicinal properties of the genus Achillea, DARU: J. Fac. Pharm. Tehran University of Medical Sciences, 19 (3), 173.

[9] M. Butnariu and I. Sarac (2018). Essential oils from plants. J. Biotechnol. Biomed. Sci. 1, 35-43. 
[10] J. Sharifi-Rad, A. Sureda and G. Tenoreetal (2017). Biological activitiesof essential oils: from plant chemoecology to traditionalhealing systems, Molecules 22(1), 70.

[11] W. Greuter (2006). Compositae (pro parte majore). In: Compositae. Euro+Med Plantbase - the information resource for Euro-Mediterranean plant diversity. Published on the Internet http://ww2.bgbm.org/EuroPlusMed/ [15 July 2021.].

[12] I.B.K. Richardson (1996). Genus Achillea In: Flora Europaea vol. 4. Cambridge University press, pp (159-165).

[13] S. Gharibi, B.E.S. Tabatabaei and G. Saeidi (2015). Comparison of essential oil composition, flavonoid content and antioxidant activity in eight Achillea species, J. Essent. Oil Bear. Plants 18 (6), 1382-1394.

[14] D.A. Sampietro, A.D.L.A. Gomez, C.M. Jimenez, E.F. Lizarraga, Z.A. Ibatayev, Y.M. Suleimen and C.A. Catalán (2017). Chemical composition and antifungal activity of essential oils from medicinal plants of Kazakhstan, Nat. Prod.Res. 31 (12), 1464-1467.

[15] D. Vidic, S. Ćavar Zeljković, M. Dizdar and Maksimović, M. (2016). Essential oil composition and antioxidant activity of four Asteraceae species from Bosnia, J. Essent. Oil Res. 28 (5), 445-457.

[16] I. Yener, M. A. Yilmaz, O. T. Olmez, M. Akdeniz, F. Tekin, N. Hasimi, M. H. Alkan, M. Ozturk and A. Ertas (2020). A detailed biological and chemical investigation of sixteen Achillea Species' essential oils via chemometric approach, Chem. Biodivers. 17 (3), e1900484.

[17] J.C. Chalchat, M.S. Gorunovic, S.D. Petrovic and V.V. Zlatkovic (2000). Aromatic Plants of Yugoslavia. II. Chemical Composition of Essential Oils of Three Wild Achillea Species: A. clavenae L., A. collina Becker and A. lingulata W. et K, J. Essent. Oil Res. 12 (1), 7-10.

[18] G. Stojanovic, R. Palic, T. Naskovic, D. Dokovic and S. Milosavljevic (2001). Volatile constituents of Achillea lingulata WK, J. Essent. Oil Res. 13 (5), 378-379.

[19] Z. Boskovic, N. Radulovic and G. Stojanovic (2005). Essential oil composition of four Achillea species from the Balkans and its chemotaxonomic significance, Chem. Nat. Compd. 41 (6), 674-678.

[20] N.N. Kovačević, M.S. Ristić, S.R. Tasić, N.R. Menković, D.V. Grubišić and D.D. Đoković (2005). Comparative study of essential oil of three Achillea species from Serbia, J. Essent. Oil Res. 17 (1), $57-$ 60.

[21] T. Kundakovic, N. Fokialakis, N. Kovacevic and I. Chinou (2007). Essential oil composition of Achillea lingulata and A. Umbellata, Flavour Fragr. J. 22 (3), 184-187.

[22] O. Jovanović, N. Radulović, R. Palić, B. Zlatković, (2010). Root essential oil of Achillea lingulata Waldst. \& Kit.(Asteraceae), J. Essent. Oil Res. 22 (4), 336-339.

[23] S. Trifunović, V. Vajs, V. Tešević, D. Djoković and S. Milosavljević (2003). Lignans from the plant species Achillea lingulata, J. Serb. Chem. Soc. 68 (4-5), 277-280.

[24] G. Stojanovic, T. Hashimoto, Y. Asakawa and R. Palic (2005). Chemical composition of the Achillea lingulata extract, Biochem. Syst. Ecol. 2 (33), 207-210.

[25] R. Palić, G. Stojanović, N. Ranđelović, V. Ranđelović and J. Veličković (2000). The fatty acids from plants of the genus Achillea, FU Phys. Chem. Tech. 2 (2), 101-104.

[26] S. Ivancheva, F. Tomas-Barberan and R. Tsvetkova (2002). Comparative analysis of flavonoids in Achillea sp. sect. Millefolium and sect. Ptarmica, C. R. Acad. 55 (5), 5-43.

[27] D. Kaczorová, E. Karalija, S. Dahija, R. Bešta-Gajević, A. Parić and S. Ćavar Zeljković (2021). Influence of Extraction Solvent on the Phenolic Profile and Bioactivity of Two Achillea Species. Molecules 26 (6), 1601.

[28] M. Alkan (2020). Chemical composition of Achillea millefolium L. (Asteraceae) essential oil and insecticidal effect against Sitophilus granarius (Coleoptera: Curculionidae) and Rhyzopertha dominica (Coleoptera: Bostrichidae), Bitki Koruma Bülteni 60 (1), 85-93.

[29] M. Aćimović, M. Zorić, V.D. Zheljazkov, L. Pezo, I. Čabarkapa, J. Stanković Jeremić, and M. Cvetković (2020). Chemical characterization and antibacterial activity of essential oil of medicinal plants from Eastern Serbia, Molecules 25 (22), 5482.

[30] D.L. Miladinović, M.V. Dimitrijević, T.M. Mihajilov-Krstev, M.S. Marković and V.M. Ćirić (2021). The significance of minor components on the antibacterial activity of essential oil via chemometrics, $L W T$ 136, 110305.

[31] L. Guz, J. Wawrzykowski and L. Adaszek (2021). Anti-babesial potential and chemical composition of essential oil from yarrow Achillea millefolium, Pol. J. Vet. Sci. 24 (1) 79-84.

[32] E. Nemeth (2005). Essential oil composition of species in the genus Achillea, J. Essent. Oil Res. 17 (5), 501-512.

[33] N. Radulovic, B. Zlatković, R. Palic and G. Stojanovic (2007). Chemotaxonomic significance of the Balkan Achillea volatiles, Nat. Prod. Commun. 2 (4), 453-474.

[34] F. Štrbac, A. Bosco, A. Amadesi, L. Rinaldi, D. Stojanović, N. Simin, D. Orčić, I. Pušić, S. Krnjajić and R. Ratajac (2020). In vitro ovicidal activity of two chemotypes of the yarrow (Achillea millefolium L.) essential oil against sheep gastrointestinal nematodes, Arch. Vet. Sci. 13 (2), 59-76. 
[35] C. El-Kalamouni, P.R. Venskutonis, B. Zebib, O. Merah, C. Raynaud and T. Talou (2017). Antioxidant and antimicrobial activities of the essential oil of Achillea millefolium L. grown in France, Medicines 4 (2), 30.

[36] H. Van Den Dool and P. D. Kratz (1963). A generalization of the retention index system including linear temperature programmed gas-liquid partition chromatography, J. Chromatogr. A 11, 463-471.

[37] R.P. Adams (2007). Identification of essential oil components by gas chromatography/mass spectrometry, 4th ed., Allured Publ. Corp, Carol Stream, IL.

[38] R. Re, N. Pellegrini, A. Proteggente, A. Pannala, M. Yang and C. Rice-Evans (1999) Antioxidant activity applying an improved ABTS radical cation decolorization assay, Free Radic. Biol. Med. 26, 9-10, 12311237

[39] W. Brand-Williams, M.E. Cuvelier and C.L.W.T. Berset (1995). Use of a free radical method to evaluate antioxidant activity, LWT-Food Sci. Technol. 28 (1), 25-30.

[40] I.F. Benzie and J..J. Strain (1996). The ferric reducing ability of plasma (FRAP) as a measure of "antioxidant power": the FRAP assay, Anal. Biochem. 239 (1), 70-76.

[41] S. Kindlovits and E. Németh (2012). Sources of variability of yarrow (Achillea spp.) essential oil, Acta aliment. 41 (Supplement-1), 92-103.

[42] V. Tadić, I. Arsić, J. Zvezdanović, A. Zugić, D. Cvetković and S. Pavkov (2017). The estimation of the traditionally used yarrow (Achillea millefolium L. Asteraceae) oil extracts with anti-inflamatory potential in topical application, J. ethnopharmacol. 199, 138-148.

[43] M. Kazemi (2015). Chemical composition and antimicrobial, antioxidant activities and anti-inflammatory potential of Achillea millefolium L., Anethum graveolens L., and Carum copticum L. essential oils, J. Herb. Med. 5 (4), 217-222.

[44] F. Candan, M. Unlu, B. Tepe, D. Daferera, M. Polissiou, A. Sokmen and H.A. Akpulat (2003). Antioxidant and antimicrobial activity of the essential oil and methanol extracts of Achillea millefolium subsp. millefolium Afan. (Asteraceae), J. Ethnopharmacol. 87 (2-3), 215-220.

[45] M. Kazemi (2015). Phytochemical and antioxidant properties of Achillea millefolium from the Eastern Region of Iran, Int. J. Food Prop. 18 (10), 2187-2192.

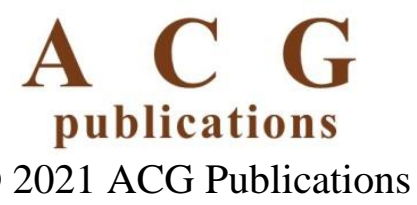

